\title{
PROFIL LIPID DAN MORTALITAS PASIEN INFARK MIOKARD AKUT DI RSUD PANEMBAHAN SENOPATI TAHUN 2015
}

\author{
Miftafu Darussalam ${ }^{1 *}$, Muhamat Nofiyanto ${ }^{2}$ \\ ${ }^{* 1,2}$ Stikes Jenderal Achmad Yani Yogyakarta Jln. Ringroad Barat, Ambarketawang, Gamping, Sleman, \\ D.I.Yogyakarta 55294, email: darusners@gmail.com
}

\begin{abstract}
Background: Lipid profile is important as supporting data for patients with heart problem as it is a state of fat seen in the levels of total cholesterol, LDL, HDL, and triglycerides. Disorders of lipid metabolism characterized by an increase or decrease in blood plasma is called dyslipidemia. Dyslipidemia has a close relationship with the occurrence of atherosclerosis and Acute Myocardial Infarction (AMI) as one of the leading causes of death.

Objective: To determine the relationship between lipid profile with the incidence of mortality in patients with acute myocardial infarction of Panembahan Senopati Bantul Hopsital in 2015.

Methods: This study used a descriptive exploratory design with data retrieved from Panembahan Senopati Bantul District Hospital 2015 medical record with a total of 106 respondents. To analyze the data, the researchers used the Lamda test.

Results: There are associations between mortality and: total cholesterol $(p=.006)$ with strong level of closeness (.647); LDL $(p=.009)$ with strong the level of closeness (.647); HDL ( $p=.017)$ with strong enough level of closeness $(.529)$; and triglycerides $(p=.003)$ with strong level of closeness $(.765)$.

Conclusion: Mortality of AMI was statistically significant associated with total cholesterol, HDL, LDL, and triglycerides.
\end{abstract}

Keywords: Acute Myocardial Infarction (AMI), lipid profile, mortality of AMI

\section{PENDAHULUAN}

Profil lipid penting sebagai data penunjang pada pasien jantung. Profil lipid adalah keadaan lemak yang dilihat dari kadar kolesterol total, LDL, HDL, dan Trigliserida. Kelainan metabolisme lipid yang ditandai dengan peningkatan maupun penurunan fraksi lipid di dalam plasma darah disebut dislipidemia. ${ }^{1}$ Dislipidemia memiliki hubungan erat dengan terjadinya aterosklerosis dan berujung pada IMA. ${ }^{2}$ Pasien dengan SKA memiliki kadar kolesterol LDL yang tinggi dan kadar kolesterol HDL yang rendah. ${ }^{3} \mathrm{Hal}$ ini bisa dikarenakan adanya kerusakan pada lapisan endotel pembuluh darah koroner yang salah satu faktor risikonya disebabkan oleh oksidasi dari LDL-C. Kematian sel endotel akibat terjadinya oksidasi LDL ini menghasilkan respons inflamasi. Di mana respons dari angiotensin II, yang menyebabkan gangguan vasodilatasi, dan mencetuskan efek protrombik dengan melibatkan platelet dan faktor koagulasi. Hal ini menghasilkan respons protektif di mana akan terbentuk lesi fibrofatty dan fibrous, plak atherosklerotik, yang dipicu oleh inflamasi. Plak yang terjadi dapat menjadi tidak stabil (vulnerable) dan mengalami ruptur sehingga terjadi SKA yang salah satunya adalah IMA.

Pasien IMA mempunyai risiko mortalitas yang tinggi, dikarenakan akan mengalami gangguan regulasi sirkulasi. Proses dimulai dengan obstruksi anatomis atau fungsional arteri koroner yang mengakibatkan iskemia 
miokardium regional, jika iskemia menetap pada infark. Jika infark yang terjadi cukup luas maka akan mengakibatkan penekanan pada fungsi ventrikel kiri sehingga akan menurunkan volume sekuncup dan meningkatkan tekanan pengisian. Jika terjadi nekrosis ventrikel kiri yang luas maka akan dapat mengakibatkan kegagalan pompa jantung dan ke semua mekanisme ini akan mengakibatkan kematian pada pasien IMA. ${ }^{4}$ Apabila terjadi kehilangan 40\% masa ventrikel kiri baik yang terjadi secara akut atau merupakan kombinasi dengan miokardium yang mengalami skar akibat infark lama. Maka akan terjadi shock kardiogenik, di mana shock kardiogenik menyumbang angka mortalitas pasien jantung sebesar $44 \%{ }^{5}$

Infark Miokard Akut (IMA) adalah suatu kondisi yang dihubungkan dengan iskemia atau nekrosis pada sel miokard yang terjadi bila sirkulasi ke daerah tersebut tersumbat. ${ }^{6}$ Aterosklerosis digunakan sebagai istilah penyakit yang diakibatkan oleh gangguan penyimpanan lemak, seperti kelebihan partikel LDL yang terakumulasi dalam dinding arteri dan menjalani perubahan kimiawi. LDL yang berlebih menyebabkan perangsangan dari monosit sehingga LDL terakumulasi di dalam sel endotel dan di dalam lapisan intima mengeluarkan sitokin yang diinduksikan oleh sel $\mathrm{T}$ tubuh. Di dalam lapisan intima monosit aktif menjadi makrofag. Makrofag dan sel $\mathrm{T}$ menghasilkan beberapa mediator radang salah satunya adalah sitokin yang mempengaruhi sel endotel. Makrofag ini akan memakan LDL sehingga menjadi sel busa dan menyebabkan plak aterosklerosis. ${ }^{7}$ Selain itu berdasarkan pada teori konvensional, fatty streaks (stadium awal dari atheroma) berkembang menjadi complicated plaques melewati multiplikasi smooth muscle cells di sekitar plak, di mana di bawahnya terdapat banyak matrik ekstraselular. Perkembangan plak di arteri koroner akan mengakibatkan mengecilnya lumen arteri hingga akhirnya mengakibatkan terganggunya aliran darah dan mengakibatkan infark miokard yang bisa berujung kematian mendadak. ${ }^{8}$

Dislipidemia yang merupakan salah satu dari faktor risiko penyakit PJK ini adalah abnormalitas kadar lipid di darah yang memengaruhi proses aterosklerotik. Dislipidemia merupakan faktor risiko mayor untuk terjadinya PJK, dengan tingginya kadar kolesterol total, LDL, dan trigliserida serta rendahnya kadar High Density Lipoprotein (HDL) dapat meningkatkan risiko PJK dan stroke iskemik. Profil lipid yang sering diperiksa antara lain, trigliserida, kolesterol total, LDL, dan HDL.

Peran kolesterol LDL dalam menyebabkan aterosklerosis telah banyak diketahui. Hal ini juga telah banyak diketahui bahwa kolesterol HDL mampu melindungi pembuluh darah terhadap aterosklerosis (antiaterogenik). Peningkatan kadar kolesterol LDL dan menurunnya kadar 
kolesterol HDL dapat meningkatkan risiko PJK. $^{9}$

\section{BAHAN DAN CARA PENELITIAN}

Penelitian ini merupakan penelitian kuantitatif non eksperimental. Rancangan penelitian ini menggunakan kohort retrospektif, yaitu untuk mengetahui hubungan antara variabel independen (faktor risiko) dengan variabel dependen (outcome) berdasarkan perjalanan waktu dimulai dari identifikasi faktor risiko sampai terjadinya outcome, namun seluruh kejadian terjadi di masa lalu (retrospektif). ${ }^{10}$ Penelitian ini dilakukan di bagian rekam medis RSUD Panembahan Senopati Bantul pada bulan Agustus tahun 2016 dengan jumlah sampel 106 responden. Analisis data yang digunakan dalam penelitian ini adalah menggunakan analisis statistik korelasional koefisien Lamda.

\section{HASIL DAN PEMBAHASAN}

Hasil analisis menunjukkan bahwa sebagian besar umur dengan kategori di atas 60 tahun sebanyak 59 (54.6\%) responden, jenis kelamin laki-laki 64 (59.3\%) responden, jenis IMA yaitu STEMI dan NSTEMI masing- masing 53 (50\%) responden, nilai kolesterol total normal dan tinggi masing-masing 40 (37.7\%) responden, nilai LDL normal 57 (53.8\%) responden, nilai HDL normal 63 (59.4\%) responden, dan trigliserida normal $67(63.2 \%)$ responden.

Tabel 1 Distribusi responden berdasarkan karakteristik usia, jenis kelamin, jenis IMA, dan profil lipid Di RSUD Panembahan Senopati Bantul Tahun 2015 ( $N=106)$

\begin{tabular}{lcc}
\hline $\begin{array}{l}\text { Karakteristik } \\
\text { Responden }\end{array}$ & Frekuensi & $\begin{array}{c}\text { Persentase } \\
(\%)\end{array}$ \\
\hline Usia & & \\
18-40 tahun & 5 & 4.6 \\
$41-60$ tahun & 42 & 38.9 \\
$\quad$ Di atas 60 & 59 & 54.6 \\
tahun & & \\
Jenis Kelamin & & \\
$\quad$ Laki-laki & 64 & 59.3 \\
$\quad$ Perempuan & 42 & 38.9 \\
Jenis IMA & & \\
$\quad$ NSTEMI & 53 & 50 \\
$\quad$ STEMI & 53 & 50 \\
Kolesterol total & & \\
$\quad$ Normal & 40 & 37.7 \\
$\quad$ Rendah & 26 & 24.5 \\
$\quad$ Tinggi & 40 & 37.7 \\
LDL & & \\
$\quad$ Normal & 57 & 53.8 \\
$\quad$ Tinggi & 49 & 46.2 \\
HDL & & \\
$\quad$ Normal & 63 & 59.4 \\
$\quad$ Rendah & 43 & 40.6 \\
Trigleserida & & \\
$\quad$ Normal & 67 & 63.2 \\
$\quad$ Rendah & 3 & 2.8 \\
Tinggi & 36 & 34 \\
\hline
\end{tabular}


Tabel 2 Tabulasi silang karakteristik responden dengan mortalitas pasien IMA di Di RSUD Panembahan Senopati Bantul Tahun 2015 ( $\mathrm{N}=106)$

Status Mortalitas

\section{TOTAL}

Karakteristik responden

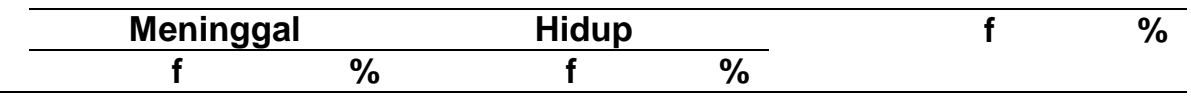

Umur

18-40 tahun

41-60 tahun

Di atas 60 tahun

0

$0 \quad 0$

enis Kelamin

Laki-laki

Perempuan

6

5.7

4.7

5

4.7

11

10.4

36

34

42

39.6

nis IMA

11

10.4

48

45.3

$\begin{array}{ll}59 & 55.7\end{array}$

STEMI

6

5.7

$53 \quad 50$

$64 \quad 60.4$

NSTEMI

8.5

36

34

$42 \quad 39.6$

9

7.5

$44 \quad 41.5$

$45 \quad 42.5$

53

53

50

50

Tabel 3 Hasil analisis antara kolesterol total, LDL, HDL, dan trigliserida dengan mortalitas pasien IMA di RSUD Panembahan Senopati Bantul Tahun 2015 ( $N=106)$

\begin{tabular}{|c|c|c|c|c|c|c|c|c|}
\hline \multirow{3}{*}{ Profil Lipid } & \multicolumn{4}{|c|}{$\begin{array}{c}\text { Status } \\
\text { Mortalitas }\end{array}$} & \multicolumn{2}{|c|}{ TOTAL } & \multirow[t]{3}{*}{$\mathbf{r}$} & \multirow{3}{*}{$P$ value } \\
\hline & \multicolumn{2}{|c|}{ Meninggal } & \multicolumn{2}{|c|}{ Hidup } & \multirow{2}{*}{$\mathbf{N}$} & \multirow{2}{*}{$\%$} & & \\
\hline & $\mathbf{n}$ & $\%$ & $\mathbf{N}$ & $\%$ & & & & \\
\hline \multicolumn{9}{|l|}{ Kolesterol total } \\
\hline Normal & 8 & 7.5 & 32 & 30.2 & 40 & 37.7 & 0.647 & \multirow{3}{*}{0.006} \\
\hline Rendah & 5 & 4.7 & 21 & 19.8 & 26 & 24.5 & & \\
\hline Tinggi & 4 & 3.8 & 36 & 34 & 40 & 37.7 & & \\
\hline \multicolumn{9}{|l|}{ LDL } \\
\hline Normal & $\begin{array}{l}1 \\
1\end{array}$ & 10.4 & 46 & 43.4 & 57 & 53.8 & 0.647 & \multirow[t]{2}{*}{0.009} \\
\hline $\mathrm{HDL}^{\text {Tinggi }}$ & 6 & 5.7 & 43 & 40.6 & 49 & 46.2 & & \\
\hline Normal & 6 & 5.7 & 57 & 53.8 & 63 & 59.4 & 0.529 & \multirow[b]{2}{*}{0.017} \\
\hline Rendah & $\begin{array}{l}1 \\
1\end{array}$ & 10.4 & 32 & 30.2 & 43 & 40.6 & & \\
\hline \multicolumn{9}{|l|}{ Trigleserida } \\
\hline Normal & 8 & 7.5 & 59 & 55.7 & 67 & 63.2 & 0.765 & \multirow{3}{*}{0.003} \\
\hline Rendah & 0 & 0 & 3 & 2.8 & 3 & 2.8 & & \\
\hline Tinggi & 9 & 8.5 & 27 & 25.5 & 36 & 34 & & \\
\hline
\end{tabular}

Hasil analisis menunjukkan bahwa sebagian besar responden yang meninggal adalah di atas 60 tahun sebanyak 11 (10.4\%) responden, jenis Kelamin laki-laki sebanyak $11(10.4 \%)$ responden, dan jenis IMA adalah STEMI sebanyak 9 (8.5\%) responden.

Hasil analisis menunjukan adanya hubungan mortalitas dengan kolesterol total dengan P: 0.006 dan tingkat keeratan kuat (0.647), LDL dengan P: 0.009 dan tingkat keeratan kuat (0.647), HDL dengan P: 0.017 dan tingkat keeratan cukup kuat (0.529), trigliserida dengan P:0.003 dan tingkat keeratan kuat (0.765).

Pada penelitian ini menunjukkan mayoritas responden yang meninggal adalah di atas 60 tahun dengan jumlah 11 (10.4\%) 
responden. Penelitian lain didapatkan pasien pria mengalami serangan tertinggi terjadi pada kisaran umur 55-59 tahun sebesar 239 $(29,4 \%)$ dan pada wanita pada rentang usia 60-64 tahun adalah 110 (36,4\%). ${ }^{11}$ Data ini menunjukkan bahwa baik serangan dan mortalitas IMA berhubungan erat dengan usia. Lebih dari 40\% pasien SKA usia lanjut disertai dengan gagal jantung dan syok kardiogenik saat dirawat di rumah sakit. Selain itu kejadian iskemia dan infark berulang juga lebih sering dijumpai pada lansia, sebagai akibat fungsi sistolik ventrikel kiri yang mengalami penurunan. ${ }^{12}$

Proses aterosklerosis dimulai sejak masa anak dan perjalanannya lambat, dimulai dengan fatty streak, yakni akumulasi kolesterol pada endotel. Fatty streak ini tidak disertai gejala klinis dan dapat berkembang menjadi ateromata atau hilang dengan sendirinya. Hiperlipidemia merupakan penyebab aterosklerosis yang penting, di mana pada banyak penelitian membuktikan bahwa aterosklerosis atau prekursor aterosklerosis dimulai pada masa anak-anak dan akan mulai muncul gejala ketika sudah mulai dewasa. Sesuai dengan penelitian ini, bahwa kolesterol total tinggi pada penelitian ini mempunyai persentase $37.7 \%$ responden dan $3.8 \%$ responden meninggal dunia. Kadar kolesterol total darah yang sebaiknya adalah <200 mg/dl, bila >200 mg/dl kolesterol tersebut akan disimpan dan menempel di dalam pembuluh darah, sehingga nantinya akan menimbulkan pengendapan kolesterol di dalam pembuluh darah. Secara klinis digunakan untuk menentukan faktor risiko penyakit jantung, walau secara patofisiologi yang berperan sebagai faktor risiko adalah LDL. $^{13}$

Jumlah HDL yang rendah pada penelitian ini berjumlah 43 (40.6\%) responden dengan jumlah yang meninggal dunia adalah 11 (10.4\%) responden. HDL mempunyai tugas untuk mengambil kolesterol yang tersimpan di makrofag kembali ke hati dan melalui VLDL dan IDL. HDL menghalangi aterosklerosis secara langsung, dengan menghilangkan kolesterol dari sel busa, menghambat oksidasi LDL, serta dengan membatasi proses peradangan yang mendasari aterosklerosis. Apabila terjadi penurunan kadar kolesterol HDL, akan mengurangi peran HDL sebagai penangkap kolesterol pada pengangkutan balik kolesterol dari jaringan ke hati, sehingga kolesterol yang menumpuk di sepanjang dinding pembuluh darah tidak diangkut kembali ke hati. Hal tersebut nantinya akan menyebabkan pembentukan plak karena penumpukan kolesterol di sepanjang dinding pembuluh darah (aterosklerosis). ${ }^{14}$ Jadi semakin tinggi kadar HDL, maka akan semakin besar pula kadar kolesterol jahat yang diangkut. Kadar HDL dapat mengalami penurunan karena beberapa faktor, yaitu faktor genetik, diabetes mellitus tipe 2, merokok, obesitas, dan pola hidup yang buruk. ${ }^{15}$ 
Kadar LDL kolesterol $>130 \mathrm{mg} / \mathrm{dl}$ akan meningkatkan risiko terjadinya infak miokard akut. Hasil penelitian ini menunjukkan kadar LDL tinggi sebanyak 49 (46.2\%) responden dengan yang meninggal selama perawatan berjumlah 6 (5.7\%) responden. LDL yang ada di dalam plasma akan mengalami oksidasi lalu ditangkap oleh makrofag dan akan menjadi sel busa (foam cell). Ini yang mendasari proses aterosklerotik pada penyakit jantung koroner. Makin banyak LDL dalam plasma makin banyak yang mengalami oksidasi dan ditangkap oleh sel makrofag. Jumlah kolesterol yang akan teroksidasi tergantung dari kadar kolesterol yang terkandung di LDL. Ketika tingkat LDL tinggi, LDL akan menumpuk di dinding arteri di mana tempat LDL teroksidasi dan diambil oleh sel busa dalam suatu proses yang mengarah pada aterosklerosis.

Kematian sel endotel akibat terjadinya oksidasi LDL ini menghasilkan respons inflamasi. Di mana respons dari angiotensin II, yang menyebabkan gangguan vasodilatasi, dan mencetuskan efek protrombik dengan melibatkan platelet dan faktor koagulasi. Hal ini menghasilkan respons protektif di mana akan terbentuk lesi fibrofatty dan fibrous, plak atherosklerotik, yang dipicu oleh inflamasi. Plak yang terjadi dapat menjadi tidak stabil (vulnerable) dan mengalami ruptur sehingga terjadi infark miokard akut.

Kadar trigliserida yang tinggi merupakan faktor risiko untuk terjadinya infark miokard akut. Kadar trigliserida tinggi adalah $>200$ $\mathrm{mg} / \mathrm{dl}$. Hasil penelitian ini menunjukkan kadar trigliserida tinggi sebanyak 36 (34\%) responden dengan yang meninggal 9 (8.5\%) responden. Trigliserida merupakan lemak utama dalam makanan. Setelah sampai di usus, trigliserida akan dikemas dalam bentuk kilomikron dan mengalami hidrolisis oleh enzim lipoprotein lipase menjadi asam lemak bebas yang akan dibawa ke hati menjadi trigliserida hati. Trigliserida dan kolesterol di hati akan disintesis menjadi VLDL (Very Low Density Lipoprotein) kemudian dibawa di dalam darah. VLDL diubah menjadi bentuk IDL selanjutnya menjadi LDL. LDL yang teroksidasi nantinya akan mendasari proses aterosklerotik, sehingga kadar trigliserida memengaruhi proses aterosklerotik pada penyakit jantung koroner ${ }^{16}$. Namun pada penelitian ini, sebagian besar mempunyai kadar trigliserida normal 67 (63.2\%) responden.

Hasil penelitian ini menunjukkan bahwa sebagian besar mempunyai kadar kolesterol total normal, LDL normal, HDL normal, dan trigliserida normal. Hal ini bisa disebabkan karena infark miokard akut disebabkan oleh banyak faktor, tidak hanya karena dislipidemia tetapi juga merokok, hipertensi, obesitas, diabetes, dan faktor keturunan. Faktor yang lain bisa dikarenakan proses aterosklerosis dapat terbentuk jauh sebelum serangan terjadi. Selain itu, pasien sudah mengurangi makanan tinggi lemak dan 
mendapatkan pengobatan sehingga kadar lipid pasien tidak tinggi lagi.

\section{KESIMPULAN}

Adanya hubungan kejadian mortalitas pasien IMA dengan kolesterol total (P: 0.006 dan tingkat keeratan kuat (0.647)), untuk LDL (P: 0.009 dan tingkat keeratan kuat $(0.647)$ ), untuk HDL (P: 0.017 dan tingkat keeratan cukup kuat (0.529)), dan untuk trigliserida (P:0.003 dan tingkat keeratan kuat (0.765)).

Maka perlunya masyarakat kabupaten Bantul untuk melakukan pencegahan IMA dengan pemeriksaan dini kolesterol total, HDL, LDL, dan trigliserida. Pelayanan kesehatan dan Dinas kesehatan Bantul untuk memberikan penyuluhan kesehatan mengenai faktor risiko IMA, sedangkan untuk penelitian selanjutnya agar lebih memperluas cakupan penelitiannya khususnya dalam jumlah variabel seperti lama hari rawat, penyakit penyerta, dan letak infark miokard.

\section{KEPUSTAKAAN}

1. Alexander, S.B. Perbedaan Profil Lipid Pada Pasien Infark Miokard Akut Dan Penyakit Jantung Non Infark Miokard Akut. Jurnal Media Medika Muda. 2013;2.

2. Senduk, B., Bodhi, W., \& Kepel, B.J. Gambaran profil lipid pada remaja obes di Kota Bitung. Jurnal e-Biomedik $(e B m)$, Volume 4, Nomor 1, JanuariJuni. 2016.

3. Faridah, E.N., Pangemanan, J.A., \& Rampengan, S.H. Gambaran profil lipid pada penderita sindrom koroner akut di rsup. Prof. Dr. R. D. Kandou periode januari - september.2015.

4. Antman, E. M. (2012). ST-Segment Elevation Myocardial Infarction : Pathology, Pathophysiology, and
Clinical Features. In: Bonow, R. O., Mann, D. L., Zipes, D. P. \& Libby, P. (eds.) Braunwald's Heart Disease: a Textbook of Cardiovascular Medicine. 9 ed. Philadelphia: Saunders. p.10881090.2012

5. Burke, A. P. danVirmani, R. Pathophysiology of Acute Myocardial Infarction. Med Clin North Am, 91, 553572; ix.2007.

6. Thygesen, K. Alpert, J.S, Jaffe, A.S, Simoons, M.L., Chaitman, B.R., \& White, H.D. Third universal definition of myocardial infarction. $J A m$ Coll Cardiol. 2012 Oct 16;60(16):1581-98.

7. Libby, P., Tabas, I., Fredman, G., \& Fisher, E. A. Inflammation and its resolution as determinants of acute coronary syndromes. Circulation research, 114(12), 1867-1879.2014.

8. Eftekhari, H., Bukharovich, I., Aziz, E. \& Hong, M. K. Epidemiology and Pathophysiology of Acute Coronary Syndrome. Di download di http://link.springer.com/chapter/10.1007 \%2F978-1-84628-869-2_4. Pada tanggal 12 Mei 2016. 2008.

9. Cordero, A., Moreno-Arribas, J., Bertomeu-González, V., Agudom P., Miralles, B., Masiá, M.D., López-Palop, R., Bertomeu-Martínez, V. (2012). Low levels of high-density lipoprotein cholesterol are independently associated with acute coronary heart disease in patients hospitalized for chest pain. Rev Esp Cardiol. 2012; 65: 305-8.

10. Dharma, K.K. Metodologi penelitian keperawatan. Jakarta : Trans Info Media.2011.

11. Deljanin, Z., Rancic, N., Ilic, M., Petrovic, B. \& Tiodorovic, B. 2007. Acute Myocardial Infarction Morbidity and Mortality in Population of 30-64 years of age in the city of Nis in the period 2001-2005 Period 2001 - 2005. Acta Medica Medianae 46(2), p. 21-24. 2007.

12. Backus, B.E., Six,A.J.,Kelder,J.H., Gibler, Moll,F.L., Doevedans,P.A. Risk 
scores for patients with chest pain: evaluation in the emergency department current cardiology reviews $2011 ; 7,2-8$.

13. Zahara F, Syafri M, Yerizel E. Gambaran Profil Lipid pada Pasien Sindrom Koroner Akut di Rumah Sakit Khusus Jantung Sumatera Barat Tahun 2011-2012. Fakultas Kedokteran Universitas Andalas. 2013.

14. Yang, N., Feng, J.P., Chen,G., Kou. L.,Li,Y., Ren. P., Zhao,L.,\& Qin,Q. Variability in lipid profile among patients presented with acute myocardial infarction, unstable angina and stable angina pectoris. European Review for Medical and Pharmacological Sciences. 2014; 18: 3761-3766. 2014.

15. Arthania, C.D.P. Perbedaan Profil Lipid Pada Pasien Diabetes Melitus Tipe 2 Dengan Komplikasi Nefropati Diabetik Stadium IV Dan Penyakit Jantung Koroner. Fakultas Kedokteran Universitas Sebelas Maret. Surakarta. 2011:48.

16. Mayes, P.A. Pengangkutan dan Penyimpanan Lipid. Dalam: Muray RK, Granner DK, Mayes PA, Rodwell VW. Biokimia Harper. ed-25 (terjemahan). Appleton \& Lange.:p 254-70. 2003. 